\title{
Notes on Recent Large-Scale Urban Maps in Japan
}

\author{
Yasuo Masai*, Shizuo NaKamura**, Kazuhiko OtaKe*** and Kiyoshi Mimura***
}

\begin{abstract}
A variety of Japanese urban maps and atlases illustrate some interesting characteristics deep-rooted in the soil of Japan. The latest years of the Tokugawa feudal period saw a great many urban picture maps designed as guide maps for Edo's population of well over one million and many other travellers. The then artistic but inaccurate maps had to be revised in the modern age after the Meiji Restoration of 1868 . Western techniques were widely introduced, and during the course of modern history, sizable amendments were made so as to depict things Japanese well on maps.

Today, the Geographical Survey Institute (GSI) is functioning as by far the most influential agent for making scientific, systematic and accurate basic maps in cooperation with local governments, other central government agencies, and private companies. GSI now publishes a 1:10,000 topographical map series for major urban areas. Local governments print 1:2,500 or 1:1,000 national large-scale maps primarily designed for urbanized areas under the guidance of GSI. For urban built-up areas, cadastral mapping at larger scales is very slowly being made due to the geographical complexity of urban areas. To meet demands for much more detailed, updated town information, several private companies publish urban maps and atlases at 1:1,000-1:2,000 including house atlases which cover all Japanese cities. These are of great practical use. Shopping and leisure town guide maps are also popular among young people. Historical urban atlases for such a city as Tokyo seem to attract specialists and the older generations, as well as culture-oriented younger people and foreigners, as a reminiscence of the past, which is not easily visible in this largest urban agglomeration in the world.
\end{abstract}

Key words: Geographical Survey Institute, national basic maps, sewerage maps, town maps, urban atlases, Japanese cities.

Large-scale urban maps are in extremely abundant supply in Japan. A large number of private companies publish all different types of largescale urban maps and atlases including so-called town maps, often thematic, which supplement growing demands. Many of these, however, use both "basic maps (kihonzu)" at 1:50,000/ $25,000 / 10,000$ and "national large-scale (national basic) maps (kokudo-kihonzu)" at 1:5,000/ $2,500 / 1,000 / 500$ as base maps. In this report, the present situation of government-produced largescale urban maps, together with some of the privately produced ones, is mostly dealt with. By large-scale it is meant a scale of 1:10,000 or larger in Japan.

\section{BASIC MAPS AND NATIONAL LARGE-SCALE MAPS}

\section{Scales}

Maps produced by the Geographical Survey Institute (Kokudo Chiri-in, GSI) of the Ministry of Construction

1:10,000 topographical maps major cities only (Fig.1)

1:5,000 national large-scale maps mountains/rural

$1: 2,500$ national large-scale maps urban

Maps produced by local governments (cities, towns, villages)

$1: 2,500$ national large-scale maps most common (Fig. 2)

\footnotetext{
*Department of Geography, Rissho University, Shinagawa-ku, Tokyo 141.

**Nakamura Map Institute, Odawara-shi, Kanagawa-ken 250.

***Geographical Survey Institute, Tsukuba-shi, Ibaraki-ken 305.
} 


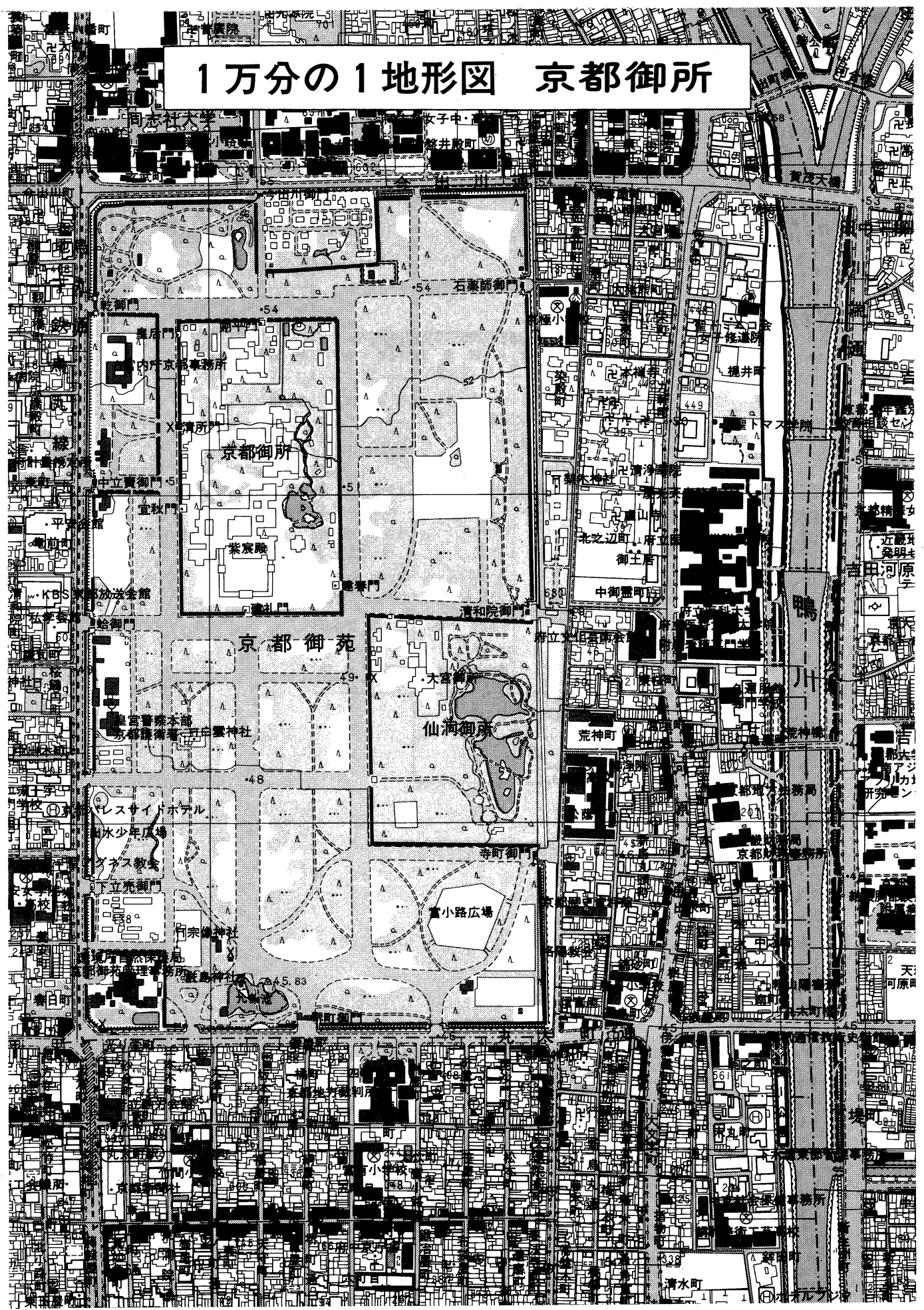

Fig. 1 1:10,000 Topographical Map (5 colors: Kyoto) 

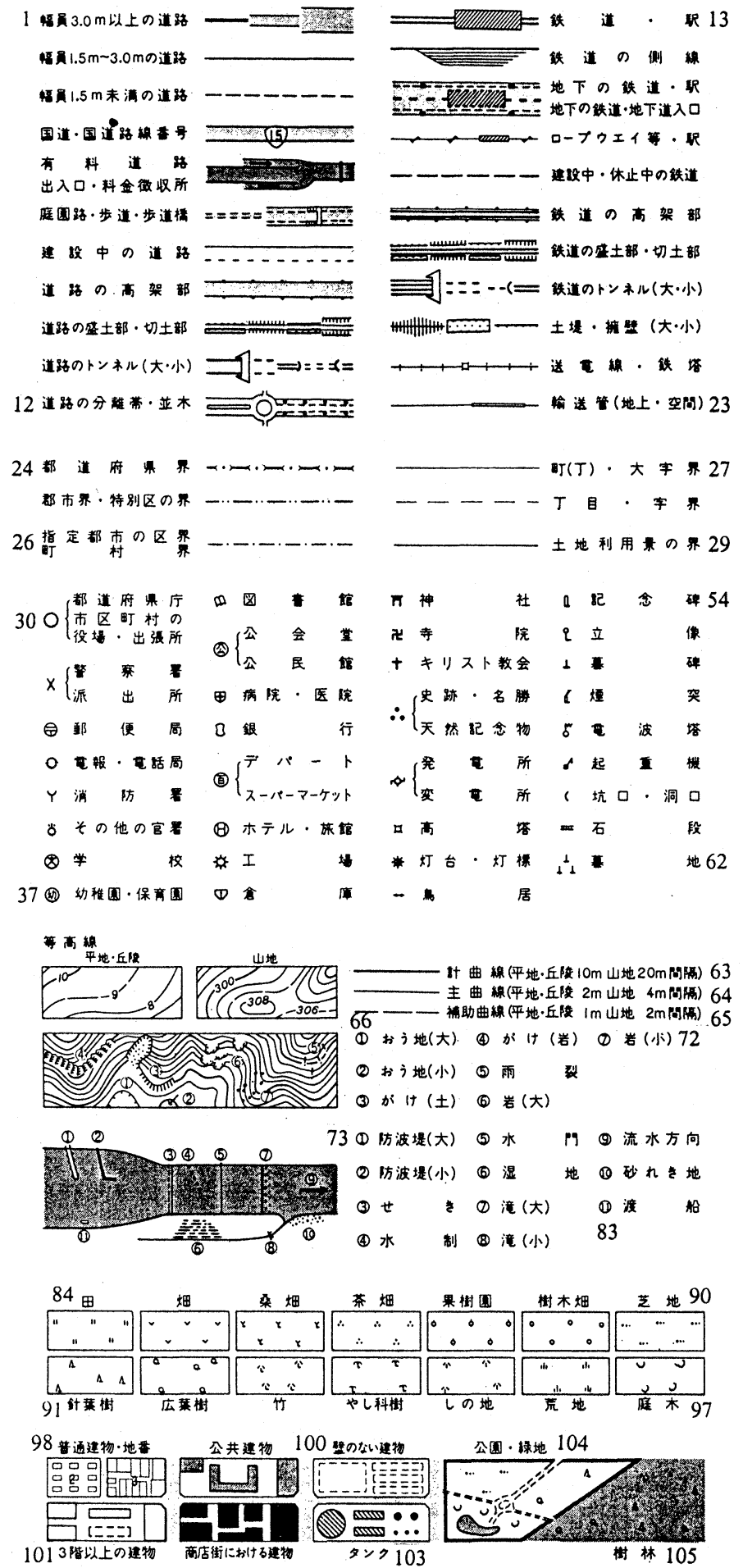

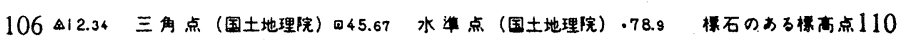

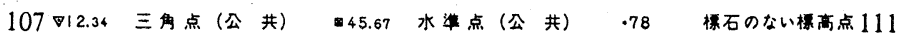




\section{1:10,000 TOPOGRAPHICAL MAPS - MAP SYMBOLS}

1 road wider than $3.0 \mathrm{~m}$

$2 \mathrm{road} 1.5-3.0 \mathrm{~m}$

3 road narrower than $1.5 \mathrm{~m}$

4 national hwy./number

5 toll road

6 toll road entrance/gate

7 garden path, sidewalk, overpass

8 road under construction

9 elevated road

10 earth-piled road, road cutting

11 road tunnel (large/small)

12 divided road, roadside trees

13 railroad, station

14 railroad sidings

15 underground railroad/sta., entrance

16 ropeway etc./station

17 railroad under constr./abolished

18 elevated railroad

19 railroad earthpiled/cutting

20 railroad tunnel (large/small)

21 dike, supporting walls (large/small)

22 power cable/tower

23 pipeline (ground level/elevated)

24 prefectural (ken) boundary

25 county, city, special ward boundary

26 ward $(k u)$, town, village boundary

27 ward subdivision, o-aza boundary

28 chome, aza boundary

29 land use boundary

30 local gov't office

31 police

32 post office

33 telecommunication office

34 fire station

35 other gov't office

36 school

37 kindergarten, nursery

38 library

39 public hall, meeting hall

40 hospital, clinic

41 bank

42 department store, supermarket

43 hotel

44 factory

45 warehouse

46 Shinto shrine

47 Buddhist temple

48 Christian church

49 historic site, natural monument

50 power plant, transmission station

51 tall tower

52 lighthouse, beacon

53 Shinto shrine gate (torii)

54 monument

55 statue

56 grave monument
57 chimney

58 electric wave tower

59 crane

60 mine gallery/cave entrance

61 stone steps

62 cemetery

63 index contour $(10 \mathrm{~m} / 20 \mathrm{~m})$

64 intermediate contour $(2 \mathrm{~m} / 4 \mathrm{~m})$

65 auxiliary contour $(1 \mathrm{~m} / 2 \mathrm{~m})$

66 hollow (large)

67 hollow (small)

68 cliff (soil)

69 cliff (rock)

70 gully

71 rocks (large)

72 rocks (small)

73 breakwater (large)

74 breakwater (small)

75 weir/dam

76 flow pressure controller

77 sluice gate

78 marsh

79 waterfall (large)

80 waterfall (small)

81 water flow direction

82 sand and gravel

83 ferry

84 paddy field ( $t a$, incl. lotus f.)

85 upland field (hatake)

86 mulberry field

87 tea field

88 orchard

89 tree field

90 lawn

91 coniferous forest

92 deciduous forest

93 bamboo

94 palm

95 bamboo grass

96 wasteland, weeds

97 garden tree/bush

98 ordinary house/bldg.

99 public bldg.

100 structure without walls

101 bldg. 3 stories or more

102 bldg. in shopping areas

103 tank

104 park/green area

105 forest, woodland

106 triangulation point (GSI)

107 triangulation point (public)

108 bench mark (GSI)

109 bench mark (public)

110 elevation with stone marker

111 elevation without stone marker 


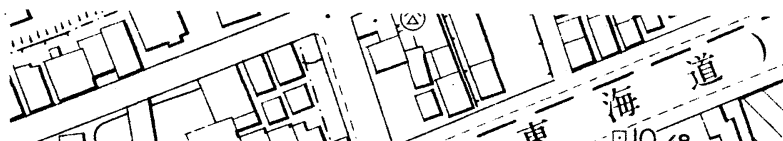

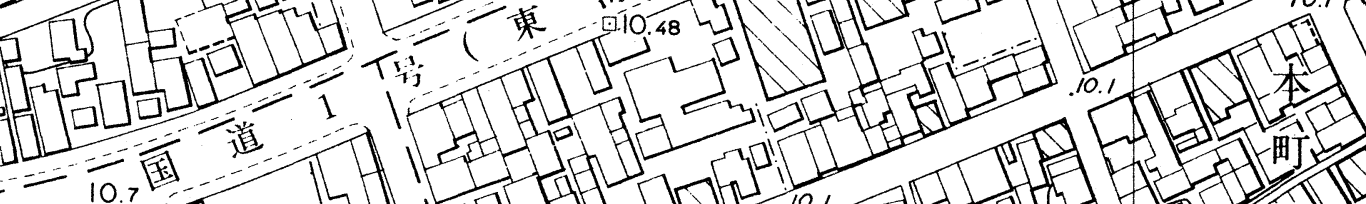
G

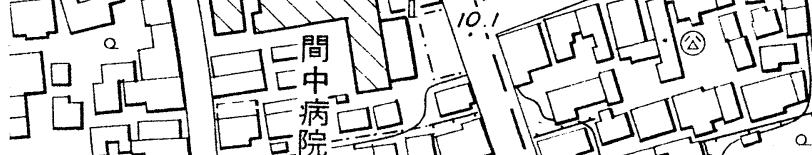

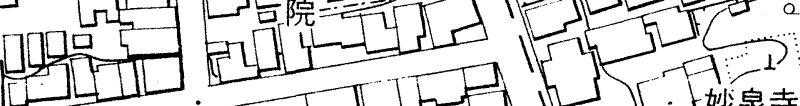

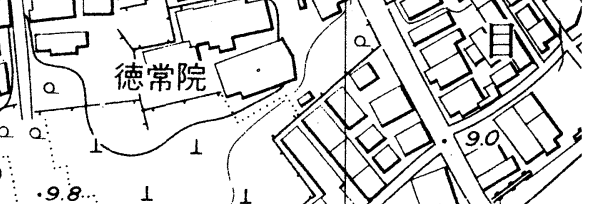

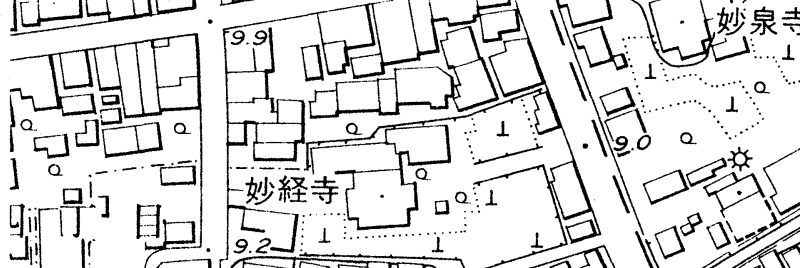

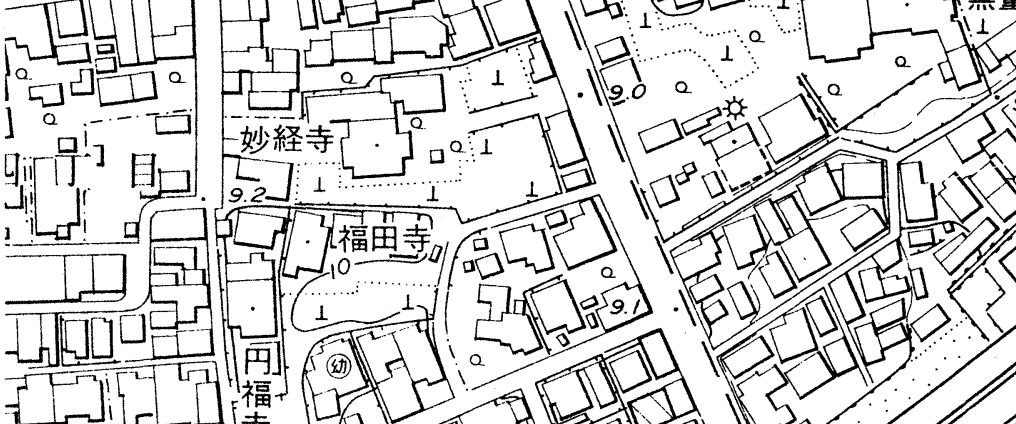
that
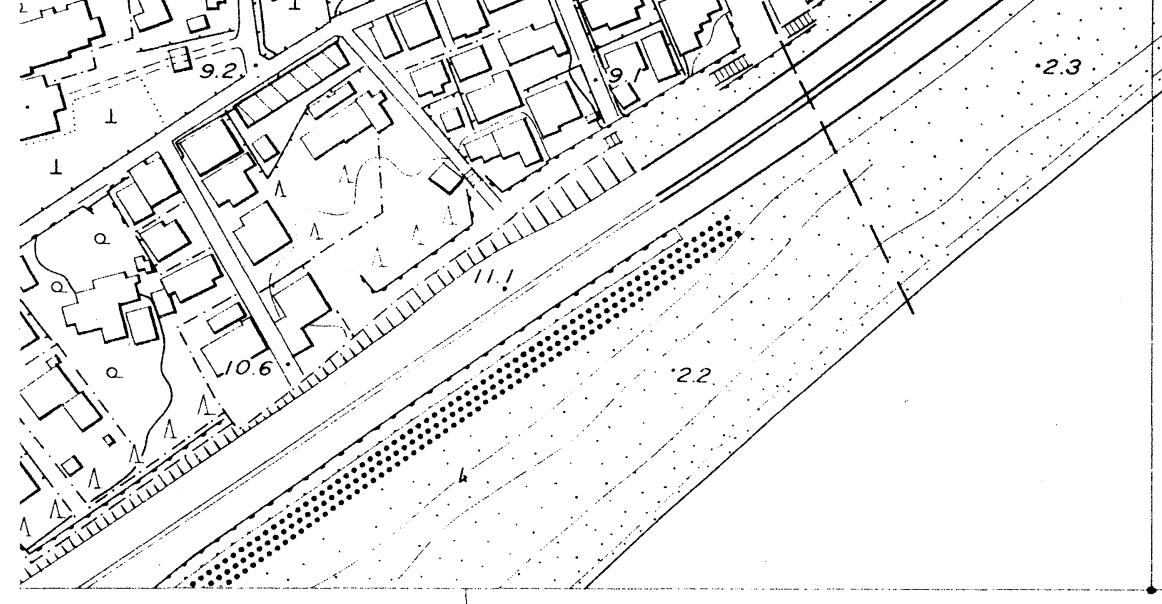

$84-2$ 


\section{1:2,500 NATIONAL LARGE-SCALE MAPS - MAPS SYMBOLS}

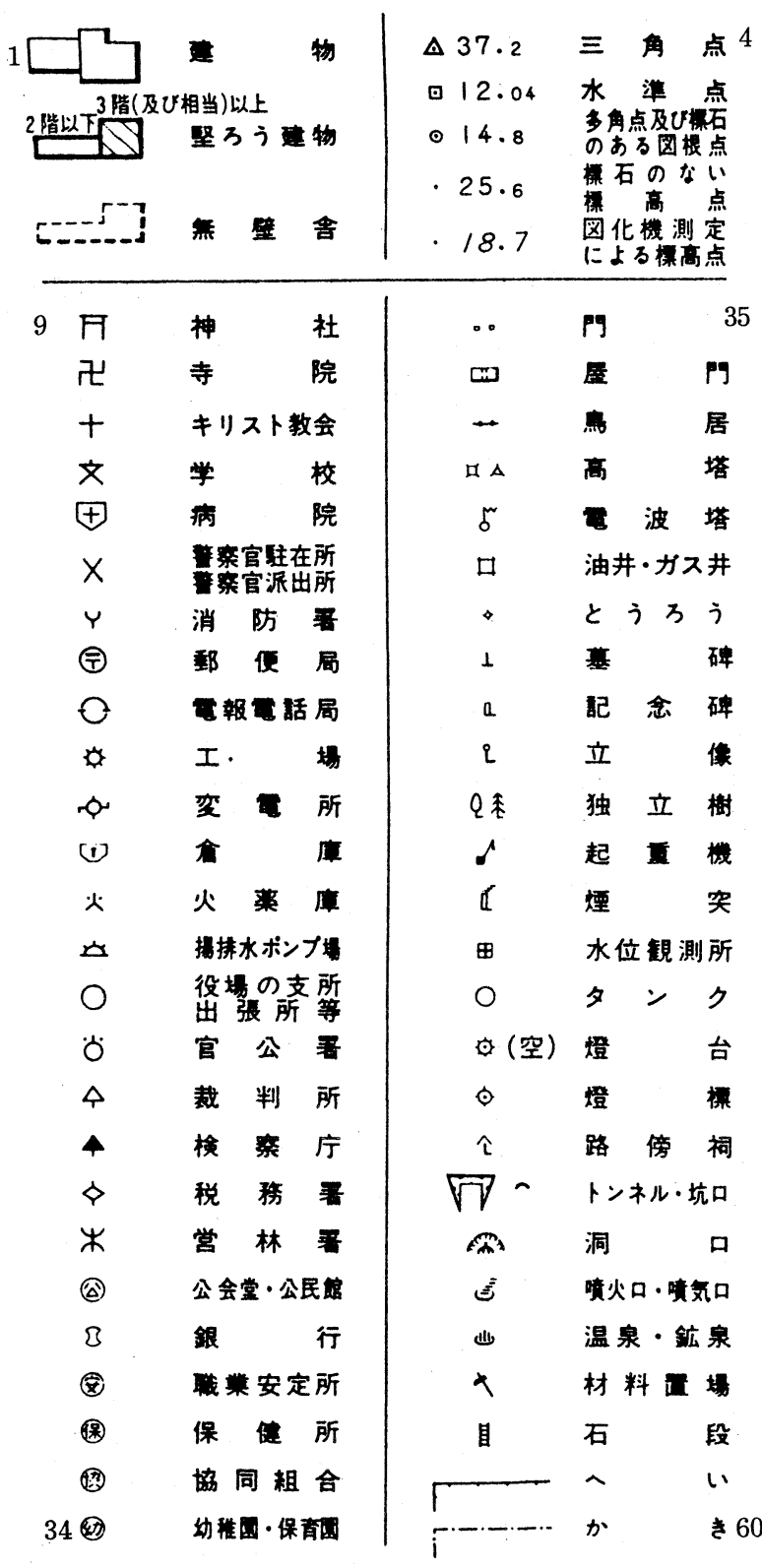

1 house, bldg., structure

2 concrete/brick bldg. 1 or 2 stories

3 stories or more

3 structure without walls

4 triangulation point

5 bench mark

6 traverse point/stone marker

7 elevation without stone marker

8 elev. measured by stereoplotter

9 Shinto shrine

10 Buddhist temple

11 Christian church

12 school

13 hospital

14 police

15 fire station

16 post office

17 telecommunication office

18 factory

19 electric transmission station

20 warehouse

21 powder magazine

22 pumping station

23 local gov't branch office

24 gov't station/office

25 courthouse

26 procurator's office

27 tax office

28 forestry office

29 public hall, meeting house

30 bank

31 employment security office

32 health center

33 cooperative

34 kindergarten, nursery

35 gate

36 house-shaped gate

37 Shinto shrine gate (torii)

38 tower

39 electric wave tower

$40 \mathrm{oil} /$ gas well

41 stone lantern

42 grave monument

43 monument

44 statue

45 single tall/big tree

46 crane

47 chimney

48 water level observation sta.

49 tank

50 lighthouse

51 beacon

52 roadside shrine

53 tunnel, mine, gallery entrance

54 cave

55 crater, fumarole

56 hotspring, mineral spring

57 construction materials depot

58 stone steps

59 wall, fence

60 hedge 

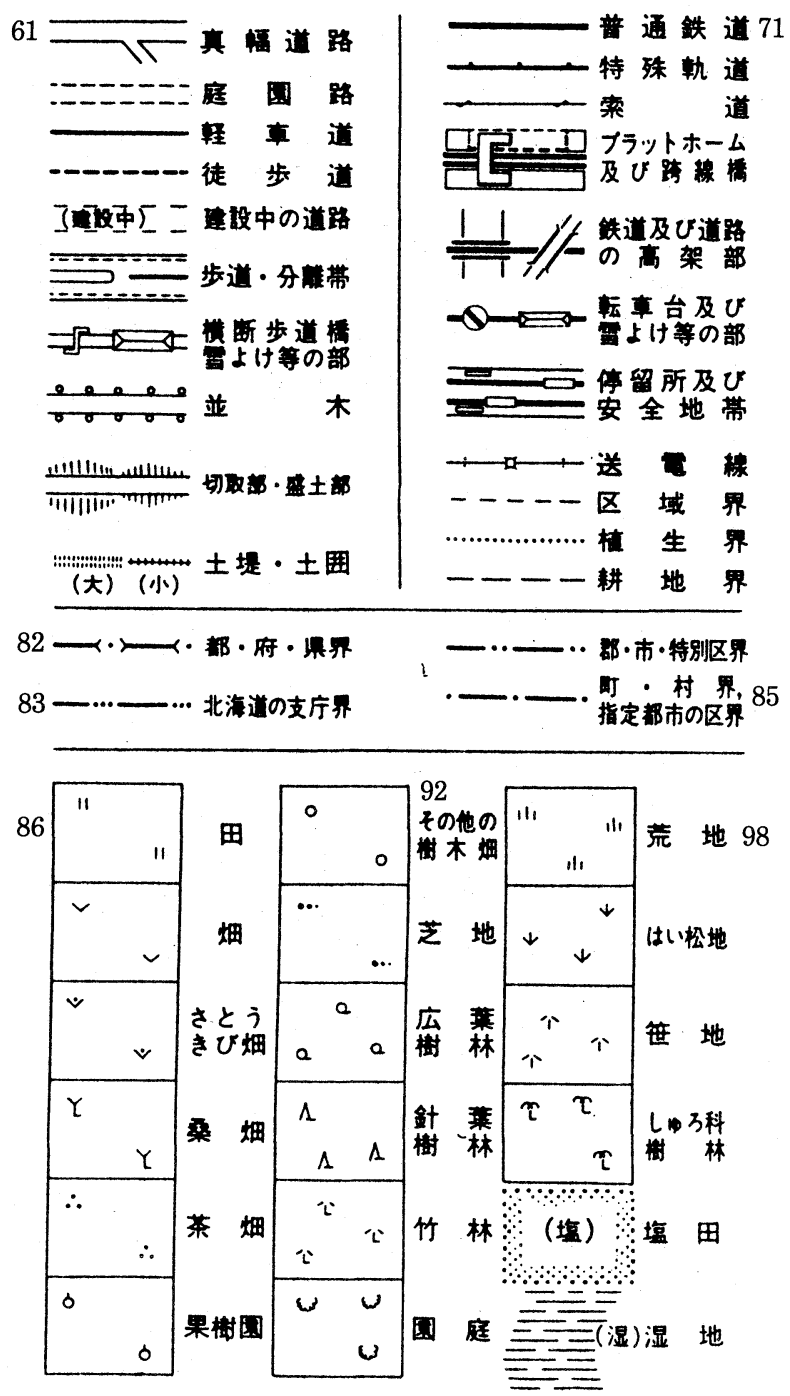

1:1,000 national large-scale maps

second most common

1:500 national large-scale maps

Cadastral maps produced by local governments in line with the National Land Agency plans

$1: 1,000 / 5,000$ cadastral maps

$1: 250 / 500$ cadastral maps rural (mostly 1:1,000) urban/rural (mostly 1:500) (Fig. 3)

GSI has been producing both 1:50,000 and 1:25,000 topographical maps for entire Japan, but the large-scale 1:10,000 topographical maps have only covered major cities including suburbs.

\author{
61 real-width road \\ 62 garden path/road \\ 63 light-vehicle road \\ 64 foot path \\ 65 road under construction \\ 66 sidewalk/divided road \\ 67 overpass/snow-shelter road \\ 68 roadside trees \\ 69 road cutting/piled-up-road \\ 70 dike \\ 71 ordinary railroad \\ 72 special railroad \\ 73 cable car/ropeway \\ 74 platform/railroad overpass \\ 75 elevated railroad/road \\ 76 turntable/snow shelter \\ 77 small platform/safety platform \\ 78 electric power cable \\ 79 area boundary \\ 80 vegetation boundary \\ 81 field boundary \\ 82 prefecture (ken) boundary \\ 83 sub-prefecture (shicho) boundary \\ 84 county/city/special ward boundary \\ 85 town/village/ward boundary \\ 86 paddy field \\ 87 upland field \\ 88 sugarcane field \\ 89 mulberry field \\ 90 tea field \\ 91 orchard \\ 92 other tree/bush field \\ 93 lawn \\ 94 deciduous forest \\ 95 coniferous forest \\ 96 bamboo forest \\ 97 garden \\ 98 wasteland, weeds \\ 99 pinus montana \\ 100 bamboo grass \\ 101 palm forest \\ 102 salt field (enden) \\ 103 marsh
}

The current 1:10,000 Series has covered much of the Tokyo-Yokohama and Kobe-OsakaKyoto metropolitan areas. It is intended to be made for all metropolitan areas and prefectural capitals. Production of this series is largely based on national large-scale maps at larger scales so as to save costly expenditures. More or less traditional cadastral maps originating about 400 years ago, known as the Taiko-kenchi survey maps produced at the time of Тоуотомі Hideyoshi or the Taiko, exist, with later revisions, for most of the inhabited areas of Japan, but accuracy is often the problem. In many cases, areas shown on these traditional cadastral maps are $10 \%$ or 

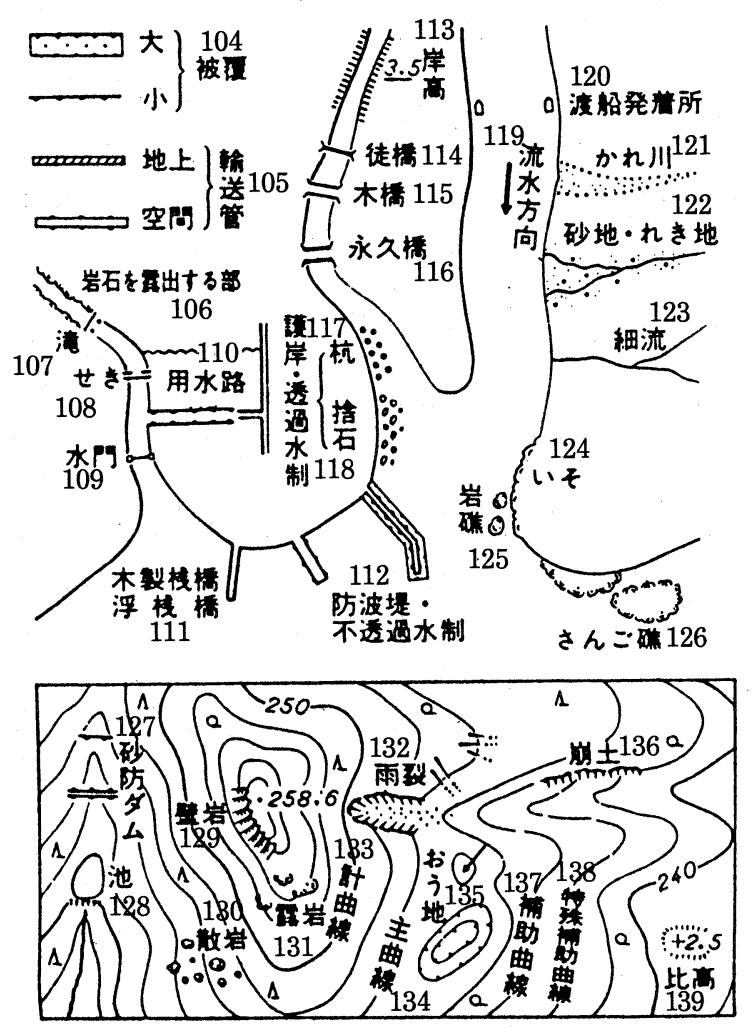

遍 加 壾 号

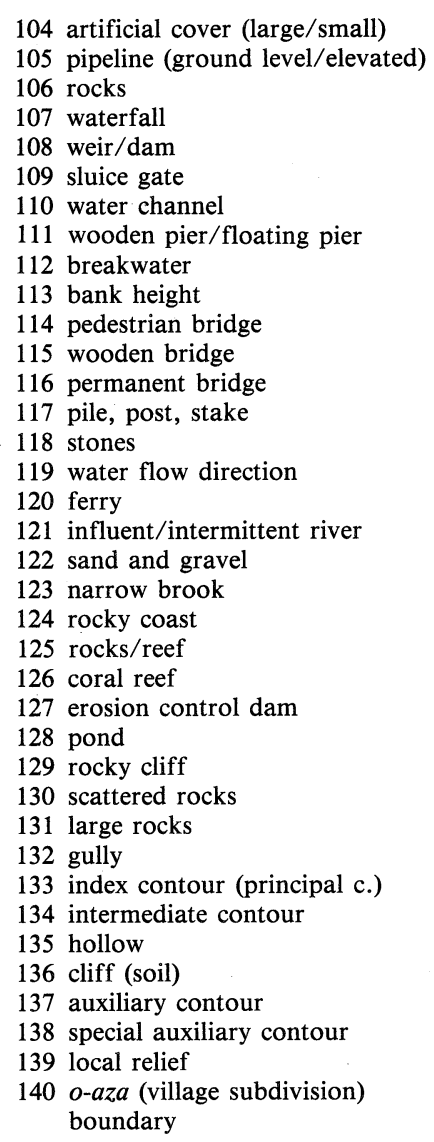

大字界 - - 140

so less than their actual value. Thus, when a house lot is purchased or a house is constructed, the lot often needs to be measured by licenced surveyors to make an accurate property boundary map. To solve this trouble-making issue, local governments are making very accurate cadastral maps under the overall direction of the National Land Agency, but coverage is yet 1/3 of the rural and suburban areas. Inner cities generally do not have accurate ones in the strict sense, since surveys are often confronted with irregularily patterned, vaguely recognized property boundaries of such high-density built-up areas.

\section{Purposes}

The major purposes of making large-scale maps by the government organizations are for planning and cadaster. Engineering purposes are normally limited to waterworks so far as government large-scale urban mapping is concerned. Private companies such as gas and/or electric companies make their own large-scale maps for their own use.

\section{Contents}

Contents vary from scale to scale, and also by theme of the maps. In the case of 1:2,500 national large-scale maps (the most commonly produced large-scale maps), well over 100 symbols are represented, as the legend above shows (Fig. 2). The 1:10,000 topographical maps contain more than 100 different symbols, too (Fig. 1). Although national large-scale maps at $1: 2,500$ illustrate all different kinds of geo-information, 


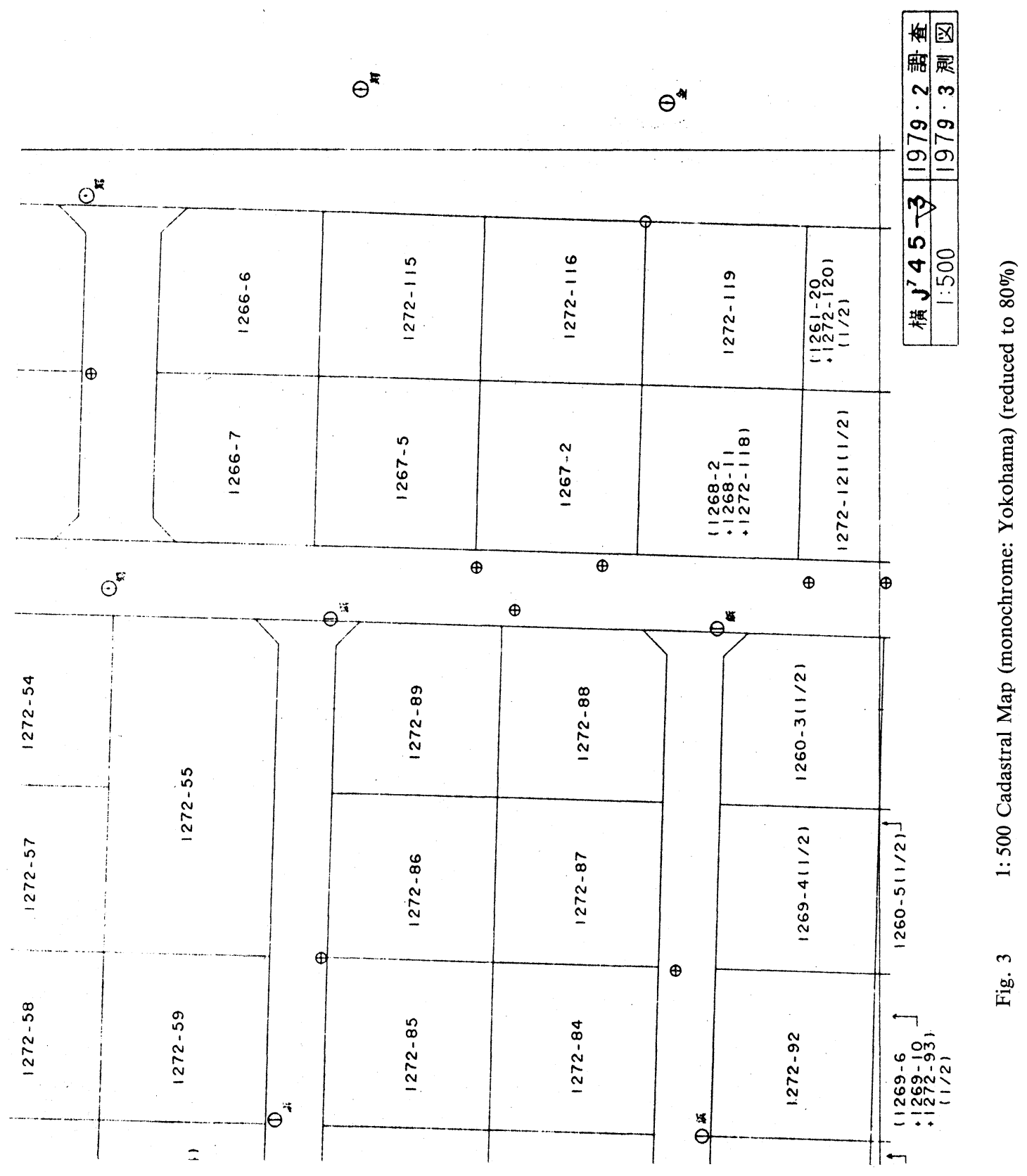


as the legend shows, altimetric or threedimensional data for manmade structures are quite limited to two categories of building height (1 2 stories and 3 or more stories). Prevalence of low buildings in historical, traditional Japanese cities and towns might have influenced this relative negligence of building height. Some of the privately produced detailed town maps show number of stories for taller buildings, however.

\section{Sheet Designation}

Japan is divided into 19 coordinates (I XIX). Each coordinate consists of grid meshes labeled with alphabet series. A grid mesh with $30 \times 40 \mathrm{~km}$ is thus labeled as IX-MC for example. This mesh is further divided into 100 subdivisions $(3 \times 4 \mathrm{~km})$, each corresponding to a 1:5,000 national largescale maps and each with a serial number (00 99). 1:2,500 national large-scale maps are obtained by dividing 1:5,000 maps into 4 equal sections $(1 \sim 4)$. Thus,

$$
\text { IX-MC 74-4 (for example) }
$$

is obtained. Formats are based on grids, not graticules.

\section{Data Acquisition and Accuracy}

$1: 2,500 \ldots \ldots \ldots \ldots$ photogrammetric survey $1: 1,000$............ photogrammetric survey $1: 500$ terrestrial and photogrammetric surveys

Table 1 Accuracy standards for topographic surveys

\begin{tabular}{|c|c|c|c|c|}
\hline & & \multicolumn{2}{|c|}{ scale } & \\
\hline & & $\geqq 1: 500$ & $\leqq 1: 1,000$ & \\
\hline \multicolumn{2}{|c|}{ planimetric location } & $\leqq \pm 0.5 \mathrm{~mm}$ & $\leqq \pm 0.7 \mathrm{~mm}$ & distance on map \\
\hline \multirow{2}{*}{ altimetric } & elevation & $\leqq \pm \Delta h / 4$ & $\leqq \pm \Delta h / 3$ & $\Delta h:$ intermediate contour interval \\
\hline & contour & & & $\Delta h:$ intermediate contour interval \\
\hline \multicolumn{2}{|c|}{ scale } & \multicolumn{3}{|c|}{ intermediate contour interval (standards) } \\
\hline \multicolumn{2}{|c|}{$1: 10,000$} & \multicolumn{3}{|c|}{$10 \mathrm{~m}$} \\
\hline \multicolumn{2}{|c|}{$1: 5,000$} & \multicolumn{3}{|c|}{$5 \mathrm{~m}$} \\
\hline \multicolumn{2}{|c|}{$1: 2,500$} & \multicolumn{3}{|c|}{$2 \mathrm{~m}$} \\
\hline \multicolumn{2}{|c|}{$1: 1,000$} & \multicolumn{3}{|c|}{$1 \mathrm{~m}$} \\
\hline \multicolumn{2}{|c|}{$1: 500$} & \multicolumn{3}{|c|}{$1 \mathrm{~m}$} \\
\hline \multicolumn{2}{|c|}{$1: 250$} & \multicolumn{3}{|c|}{$1 \mathrm{~m}$} \\
\hline
\end{tabular}

Table 2 Accuracy at index points

\begin{tabular}{lcc}
\hline \hline & & accuracy \\
\cline { 2 - 3 } scale & planimetric location* & elevation* \\
\hline $1: 500$ & $\leqq \pm 0.1 \mathrm{~m}$ & $\leqq \pm 0.1 \mathrm{~m}$ \\
$1: 1,000$ & $\leqq \pm 0.1 \mathrm{~m}$ & $\leqq \pm 0.1 \mathrm{~m}$ \\
$1: 2,500$ & $\leqq \pm 0.2 \mathrm{~m}$ & $\leqq \pm 0.2 \mathrm{~m}$ \\
$1: 5,000$ & $\leqq \pm 0.2 \mathrm{~m}$ & $\leqq \pm 0.2 \mathrm{~m}$ \\
$1: 10,000$ & $\leqq \pm 0.5 \mathrm{~m}$ & $\leqq \pm 0.3 \mathrm{~m}$ \\
\hline
\end{tabular}

*standard deviation

Table 3 Photographing scale (standards)

\begin{tabular}{ccc}
\hline \hline plotting scale & photographing scale & multiplying ratio \\
\hline $1: 500$ & $1: 3,000 \sim 1: 4,000$ & $1: 6 \sim 1: 8$ \\
$1: 1,000$ & $1: 6,000 \sim 1: 8,000$ & $1: 6 \sim 1: 8$ \\
$1: 2,500$ & $1: 10,000 \sim 1: 12,500$ & $1: 4 \sim 1: 5$ \\
$1: 5,000$ & $1: 20,000 \sim 1: 25,000$ & $1: 4 \sim 1: 5$ \\
$1: 10,000$ & $1: 30,000$ & $1: 3$ \\
\hline
\end{tabular}


Automation in data acquisition is not well developed yet. Stereoplotting is done by hand, but some experiments are being done for digital representation.

\section{Map Design}

Although 1:10,000 topographical maps for major urban areas use five colors (black, salmon pink, green, purplish dark gray, blue), all national large-scale maps at larger scales are produced monochromatically. Generalization of the distribution of houses/buildings is minimum at scales of larger than 1:10,000, enabling horizontal house shape to be represented almost as they are. Since 1:10,000 topographical maps for urban areas are basically photographical reductions of the photogrammetrically produced larger-scale maps (national large-scale maps), here also horizontal house shape is quite realistically shown. Generalization of road widths is applied for very narrow roads which abound all over. At $1: 5,000$, roads with a width of $2 \mathrm{~m}$ or wider are of real widths, and at 1:2,500, $1 \mathrm{~m}$ or wider represent real widths. Even on 1:10,000 topographical maps, pedestrian sidewalks and overpasses are normally shown, but many of the simple sidewalks such as guard-rail separation for pedestrians at a side or both sides fail to be represented. Design of government-produced maps is often criticized for not being artistic. Even the five-colored 1:10,000 topographical maps do not seem to deserve to be a decoration in a room, perhaps because of their faintness in print and also of too complicated texture and contents. Nevertheless, this series of urban maps attracts much attention from specialists thanks to its accuracy and abundant detailed geoinformation, both of which are to be realized at the relative sacrifice of artistic design.

\section{Map Production, Reproduction, and Revision}

For $1: 10,000$ topographical maps, scribing is used, but for $1: 5,000 / 2,500 / 1,000$, ink drawing is the common practice. Phototype setting is widely used for letters and some symbols. The most common materials for fair drawing are plastic. CAD (computer-aided design) has just started. National large-scale maps are produced for all parts of Japan, but in case demands do not exceed 200, maps are not printed; only blue- prints are supplied for minor demands. Revision intervals are as follows:

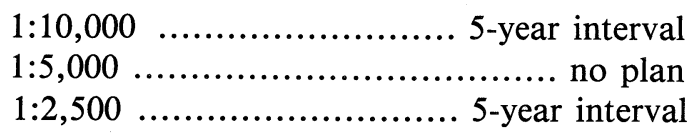

\section{SEWERAGE MAPS}

Fig. 4 is a case for Odawara City in the southwest of Tokyo, illustrating the difficulty of installing adequate sewer systems for such an irregularly patterned built-up area as this. This is a kind of base map for various purposes concerning sewage systems here, and so it does not show all aspects concerned. Workmen use this kind of map when they construct or repair, together with others such as vertical distribution maps.

The scale here is 1:500, but this is a simple enlargement from 1:600. The contour interval is $1 \mathrm{~m}$ in general, but auxiliary contours are also set for $0.5 \mathrm{~m}$ where necessary. Elevations of the major streets are surveyed very precisely, normally in $\mathrm{cm}$, but BM shows as small as mm (e.g., 10.361). Since all houses/structures seem to have different plans from each other, the construction of sewer systems is a time and money-consuming job. Many houses are located behind the houses directly facing the streets, but even these need to be supplied with sewers irrespective of locations. A small $\mathrm{T}$ letter on the map indicates "toilets", and these have to be connected with the sewers. There are many wells (encircled checkerboard) located in backyards, but most of them are no longer in use. House lot and/or property boundary lines are not clearly shown on the map. Lots and/or property separating walls or fences as visible structures are shown here, but these do not necessarily coincide with real lot and/or property boundaries. Garden trees and bushes may be represented.

\section{PRIVATELY PRODUCED TOWN GUIDE MAPS AND ATLASES}

Several private companies publish very detailed town guide/inventory maps and atlases at $1: 1,000$ to $1: 2,000$ for all cities of Japan and for 


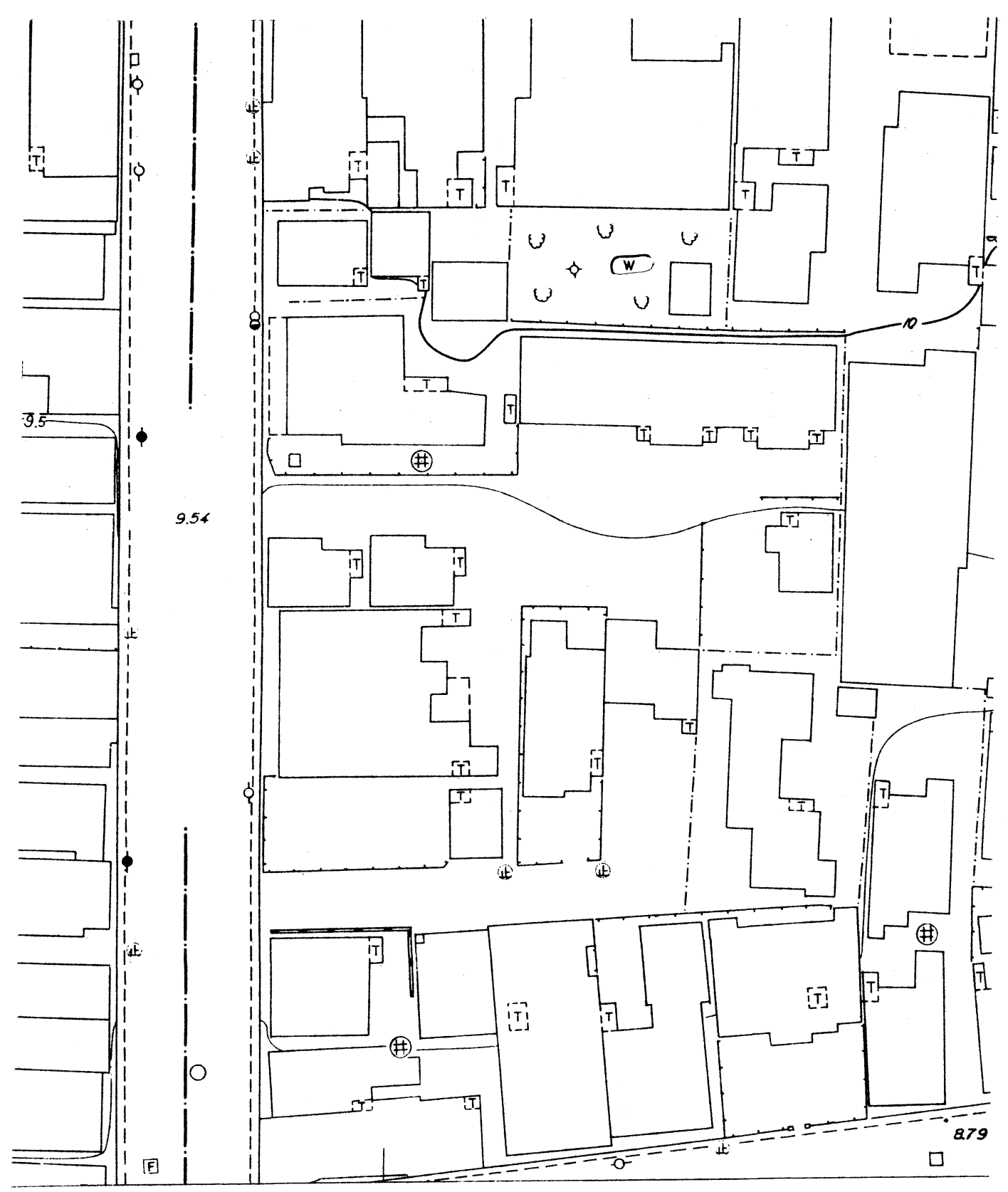

\section{$1: 500$}




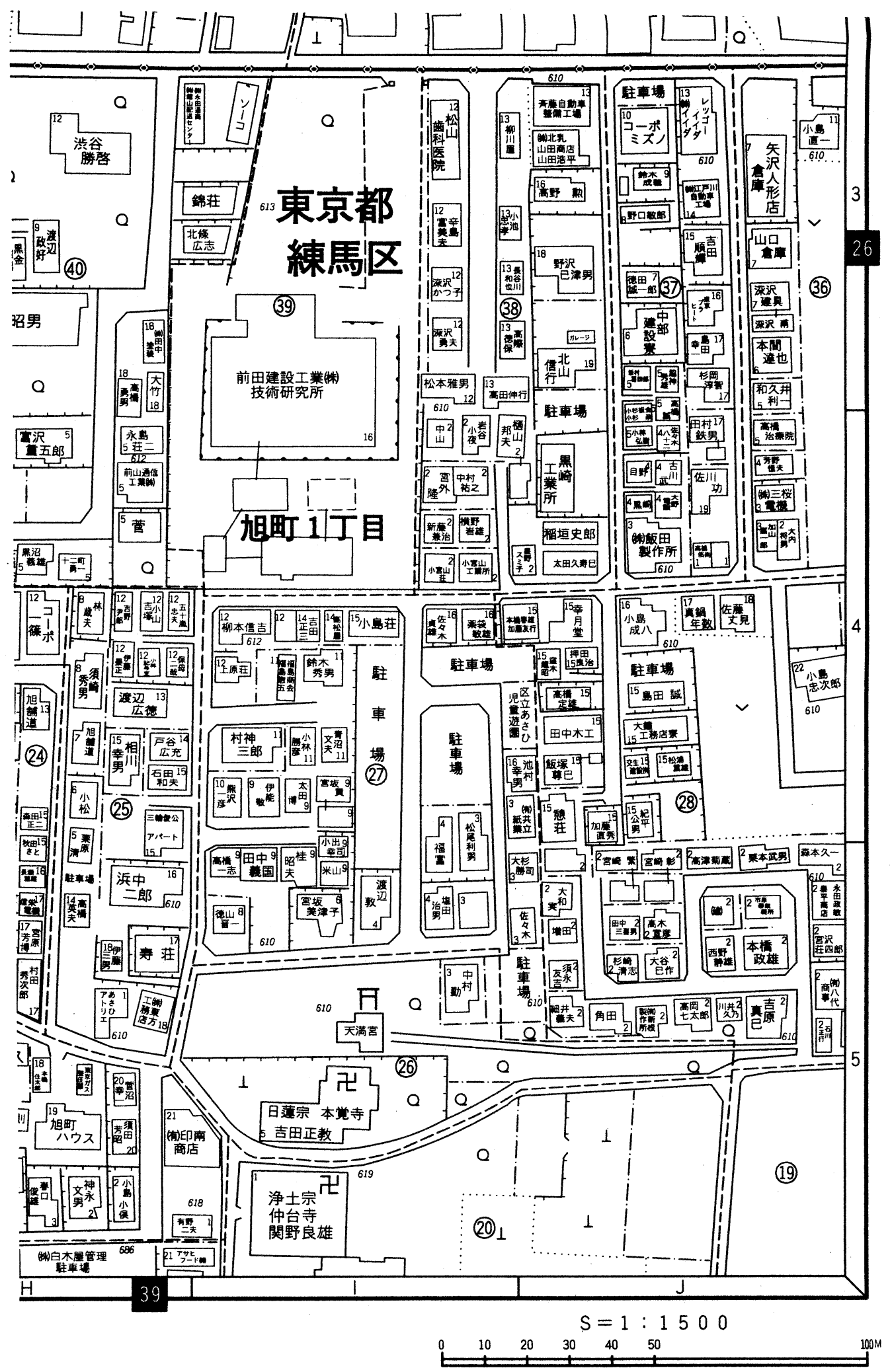

Fig. 5 1:1,500 Town Guide Map (monochrome: Tokyo) 
a great many towns and villages. These maps normally include real-width roads except for very narrow ones, houses (with surnames, often with full names, of resident representatives, names of establishments such as stores/companies/institutions), place-names, address numbers, etc. Since most of the streets in Japanese cities and towns do not have names and irregularly arranged street patterns are very complicated, this kind of town information maps and atlases are very widely used (Fig. 5).

Applicability of this kind of extremely detailed maps covering all cities is great. Many stores, banks, local governments, information bureaus and researchers can make full use of these maps. Geographical field work can easily become very efficient, with the aid of this geoinformation. Present-day urbanization here in Japan takes both horizontal and vertical expansion at a very rapid rate. Revision is made at the least interval and new additions are traced by enormous manual efforts and photo interpretation. These are commercially produced. A consequence is incomleteness in the inventory. Sometimes, they lack information inside office buildings or apartment blocks. Underground shopping malls may not be illustrated precisely.

The general lack of street names in Japan's cities and towns necessitates this kind of detailed inventory-type maps for general use. These are available at many book stores. Minor subdivisions within a city or ward often distribute similar guide maps to all residents. They may be used as shopping guides, too. The system of address numbers or house numbers in Japan seems to accelerate the need of such detailed, individualbased town maps.

Instead of street names and numbers, Japanese cities and towns use block systems. Built-up areas of metropolises are divided into wards $(k u)$, which consist, in turn, of machi. Machi are made up of a few chome, numbered from 1 to 3 or 4 . A chome is subdivided into many numbered blocks, each of which is further subdivided into last-order numbers which normally designate individual lots.

Thus: Tokyo-to, Nerima-ku, Fujimidai, 東京都練馬区 富士見台

1-chome 17-ban 15-go

1 丁目 17 番. 15 号
Japanese town guide maps tend to show very narrow streets in real widths. There are two major reasons for this fact: 1) widths of the streets are not standardized in many cases, and 2) as street names do not exist, it is not necessary to print lines wide enough apart to take a street name. This is also true with national largescale urban maps, which need to describe block names rather than street names. A result is the more or less faint (narrow) lines showing streets on Japanese maps.

Commercial town maps include some of the shopping areas, amusement zones, recreational areas, fashion towns, busy railroad stations, or the like, in very detailed, updated form. Such maps or magazines tend to focus on places and areas where young people gather. Large stations provide free computer-processed town guides including maps.

Efforts have been made to compile urban atlases for Japanese cities. Aside from planning atlases by governments, most of urban atlases are directly related to urban developments. Thanks to the existence of a large number of town maps produced during the Tokugawa feudal period, many historical urban atlases and also other urban atlases utilize these historical documents, mostly in the form of facsimile. A few reconstructed or newly designed historical urban maps have also been printed so that the scientific appraisal of the past could be made. Different from the Tokugawa period when practically all maps showed artistically deformed or intentionally distorted forms, as early maps elsewhere often illustrated, many of the new maps printed after the Meiji Restoration of 1868 tended to be scientifically accurate. Successive developments of cartographic works in Japan now enable many publishers to compile annotated atlases showing urban developments of great cities, old castle towns, newly planned cities in Hokkaido, etc. Compilation of old commercial maps and town maps is being done at places as a reminiscence of childhood or good old days.

This short paper was read before the annual meeting of the International Cartographic Association's Commission on Urban Cartography (the then Chairman: Yasuo MASAI) held at Rotterdam, the Netherlands in 1987. Gratitude is extended to the local organizer, Mr. Jan 
Meijer, of the City of Rotterdam, and the other colleagues of the Commission who gave us much useful information.

(Received Mar. 1, 1989)

(Accepted Apr. 25, 1989)

\section{References}

ASAKURA, Haruhiko, edit. (1985-87): Edo-Joka Hensen Ezu-shu (Picture Maps Showing Historical Changes of Edo Castle-town). Hara Shobo, Tokyo. (J)

KanaKubo, T., SAITO, S. and Y. EgaWA (1985): 1/10,000 Map Series in Japan. G.S.I. Bulletin, 29-2, 46 57. (E)

Kashiwa Shobo, edit. (1983): Meiji-Taisho-Showa Tokyo 1:10,000 Chikeizu Shusei (Collection of 1:10,000 Topographical Maps for Tokyo in the Meiji-TaishoShowa Periods-1883-1937), Kashiwa Shobo. (J)

(1984): Taisho-Showa Tokyo Shuhen 1:10,000 Chikeizu Shusei (Collection of 1:10,000 Topographical Maps for around Tokyo in the Taisho-Showa Periods-1917-37). (J)

(1986): Meiji-Taisho Nihon Toshi-zhizu Shusei (Collection of Japan's Urban Maps in the Meiji-Taisho Periods-1881-1926). (J)

- (1986): Showa-zenki Nihon Toshi-chizu Shusei (Collection of Japan's Urban Maps in the Early Showa Period-1928-43) (J)

Koku Jutaku-chizucho (Aerial House Atlases) (updated). Kokyo-shisetsu Chizu Koku Co. Ltd., Tokyo, Osaka and Nagoya. (J)

MASAI, Yasuo (1975): 1:20,000 Urban Land Use Map of Edo. Chizu (Map), 13-1, 9-16 (with a bilingual map, first edition 1973) (JE)

(1984): Some New Developments of Urban Cartography in Japan. Tsukuba Studies in Human Geography, VIII, 265-272. (E)

MASAI, Y. and H. PAPE, edit. (1982): Urban Cartography 1982. Commission on Urban Cartography, International Cartographic Association (ICA). (E) (1984): Urban Cartography 1983. Commission on Urban Cartography, ICA. (E) (1985): Urban Cartography No. 3. Commission on Urban Cartography, ICA. (E) (1986): Urban Cartography No. 4. Commission on Urban Cartography, ICA. (E)

Masai, Y. et al., edit. (1986): Atlas Tokyo [bilingual, Japanese and English, annotated). Heibonsha, Tokyo. (J\&E).

Ministry of Construction (1985): The Standard Specifications for Surveys for Public Projects. (E).

NAKAMURA, Shizuo (1974): Odawara: Japanese Castle and Post-town. Nakamura Map Inst. (J\&E) (1984): Hakane Rekishi-chizu (Historical Map of Hakone), Nakamura Map Inst. (J).

PArry, R. B. and C. R., Perkins, edit. (1987): World Mapping Today. Butterworth and Co., London.

Photogrammetric Survey Technical Society (1979): Toshi Kukan Kozo Kihonzu Sakusei-shuho Chosa (Survey of Techniques for Urban Spatial Structure Basic Maps). Tokyo. (J)

Sapporo Geography Circle (1986): Watching Sapporo (annotated atlas). Hokkai Times, Sapporo. (J).

Zenrin no Jutaku-chizu (Zenrin's House Atlases) (updated). Zenrin Co. Ltd., Kita-Kyushu, Tokyo and Osaka. (J). 


\title{
最近の日本の大縮尺都市地図
}

\author{
正 井 泰 夫*, 中 村 静 夫**, \\ 大 竹 一 彦***, 三 村 清 志***
}

日本の都市地図・アトラスは, 日本という風土の中で 特徵ある発達を示してきた。江戸時代に大きく発達した 絵図的都市地図は, 特に百万都市江戸に括いて都市案内 図として役立った。明治以後の近代化の過程で, 欧米の 先進技術が導入され，地図作成法も大きく変化したが, さまざまな面で日本的対応が見られたことも事実であ る。

今日, 国土地理院が大縮尺都市地図のシステム化で果 している役割は非常に大きい。また，各省庁，地方自治 体，民間企業でも，国土地理院の指導の下に，または密 接な協力関係に抢いて, 詳細な大縮尺地図を作成してい る。国土地理院は現在， $1: 10,000$ 地形図シリーズを刊 行中であり，これは全国の主要都市へ適応されることに なっている。地方自治体等でも，国土地理院の設定した ガイドラインの下に, $1: 5,000$ から $1: 2,500$ 程度の大
縮尺地形図を作成している。市街地でも地籍図の作成が 少しずつ進められているが，正確な地籍図を全面的に完 成させるには，従来からの足かせが余りにも大きい。

きわめて詳細なタウンマップの重要性は特に主題図に 扔いて高い。民間企業による1：1,000あるいは1：2,000 程度の住宅地図類が全国的規模で出版されているが，こ の利用度は高い。主として若者向けの買物・レジャ一関 連の大縮尺タウンマップが多数出されている。歴史的都 市アトラスの作成も，東京を中心に盛んとなっている が, 大縮尺のものの出版も進久, 専門家や中高年を対象 として販路がふえている。この種の地図・アトラスは, 次第に若者や外国人の関心を呼んでいるが，これには世 界最大都市としての東京の過去に対する関心の高まりが 反映していよう。 